\title{
Commentary: Methamphetamine mediates immune dysregulation in a murine model of chronic viral infection
}

\begin{abstract}
Jennifer M. Loftis ${ }^{1,2,3 *}$
${ }^{1}$ Veterans Affairs Portland Health Care System, Research and Development Service, Portland, OR, USA, ${ }^{2}$ Department of Psychiatry, Oregon Health and Science University, Portland, OR, USA, ${ }^{3}$ Methamphetamine Abuse Research Center, Oregon Health and Science University, Portland, OR, USA
\end{abstract}

Keywords: addiction, alcohol, blood brain barrier, co-morbidity, chronic viral infection, hepatitis C, methamphetamine, $\mathrm{T}$ cells

\section{A commentary on}

Methamphetamine mediates immune dysregulation in a murine model of chronic viral infection

by Sriram, U., Haldar, B., Cenna, J. M., Gofman, L., and Potula, R. (2015). Front. Microbiol. 6:793. doi: $10.3389 /$ fmicb.2015.00793

Edited by:

Slobodan Paessler,

University of Texas Medical Branch,

USA

Reviewed by:

Dahlene N. Fusco,

Massachusetts General Hospital, USA

Juan C. De La Torre,

The Scripps Research Institute, USA

*Correspondence:

Jennifer M. Loftis

loftisj@ohsu.edu;

jennifer.loftis2@va.gov

Specialty section: This article was submitted to

Virology,

a section of the journa

Frontiers in Microbiology

Received: 28 September 2015 Accepted: 07 December 2015

Published: 23 December 2015

Citation:

Loftis JM (2015) Commentary: Methamphetamine mediates immune dysregulation in a murine model of

chronic viral infection.

Front. Microbiol. 6:1473.

doi: 10.3389/fmicb.2015.01473
The recent article by Sriram et al. (2015) is one of the first studies to evaluate the effects of methamphetamine on peripheral $\mathrm{T}$ cell responses, in the context of a chronic viral infection. Using lymphocytic choriomeningitis virus (LCMV) clone 13 as a model of chronic viral infection in mice, investigators found that exposure to methamphetamine significantly alters the expression of peripheral T cell factors putatively involved in infection control. In particular, the expression of programmed cell death protein-1 (PD-1), type 3 inflammatory CXC chemokine receptor (CXCR3), and epidermal growth factor receptor (EGFR) was increased on T cell subsets from LCMV-infected mice exposed to methamphetamine. Collectively, these immune cell changes have the potential to adversely impact key anti-viral immune functions, such as $\mathrm{T}$ cell recruitment, cytokine production, and exhaustion.

Given the high prevalence of chronic viral infections [e.g., human immunodeficiency virus (HIV) and hepatitis C virus (HCV)] associated with methamphetamine and other substance use disorders, including alcohol (Martínez-Raga et al., 2001), it is important to determine how substances of abuse effect $\mathrm{T}$ cell responses involved in the etiology and progression of chronic viral infection. Co-morbid substance use disorders and HIV and/or HCV infections are also often associated with impairments in central nervous system (CNS) function (Carey et al., 2006; Loftis et al., 2006; Butt et al., 2007; Fuller et al., 2009), which can hinder successful treatment outcomes (Fals-Stewart, 1993; Aharonovich et al., 2003). Similarly, infectious symptoms (e.g., fatigue, pain, and depression), potentially caused by substance abuse-related peripheral immunosuppression, could lead to further likelihood of relapse or increased substance use. Indeed, the tendency of adults with substance use disorders to self-medicate with alcohol and other drugs of abuse (Bolton et al., 2009; Crum et al., 2013) could be recognized as a possible complication of untreated or uncontrolled viral infection symptoms. These and other findings highlight the converging effects of substances of abuse on immune function-effects that contribute to the addiction and increase susceptibility for the progression of chronic viral infections. Despite changes in peripheral $\mathrm{T}$ cell markers associated with viral clearance, Sriram et al. (2015) reported that methamphetamine 
exposure did not significantly alter viral loads in plasma or tissues (i.e., spleen, lungs) from mice with LCMV clone 13 infection. However, it would be of interest to investigate whether or not methamphetamine exposure contributed to the invasion of virus into the brain, as LCMV (although considered to be peripherally restricted) can infect the brain and cause CNS impairments, including learning deficits (Brot et al., 1997).

Methamphetamine and other substances of abuse alter blood brain barrier (BBB) function (Haorah et al., 2008; Kousik et al., 2012; Northrop and Yamamoto, 2012) and potentially increase the invasion of peripheral viruses, such as HIV and HCV, into the brain (e.g., Gavrilin et al., 2002; Bokemeyer et al., 2011). In a previous study using a murine model of HIV-1 encephalitis, Potula et al. (2006) innovatively demonstrated the presence of CD8+ $\mathrm{T}$ cell infiltration in brain areas with HIV-1 monocytederived macrophage infection and importantly, the impairing effects of alcohol on viral clearance. Emerging evidence suggests that $\mathrm{T}$ cells may play a critical role in these processes and in the development of CNS damage resulting from viral infection and co-morbid substance abuse (Gaskill et al., 2013; Coley et al., 2015). It is noteworthy that Sriram et al. (2015) observed increased expression of $\mathrm{T}$ cell markers, which among other immune functions, play a role in the transmigration of T cells into the CNS. For example, studies show a role for CXCR3 in CD8+ T cell trafficking in the brain following intracranial LCMV infection in mice (e.g., Christensen et al., 2006), and CXCR3 has been proposed to serve as a surface marker for cells that have the ability to cross the BBB (Callahan et al., 2004). Similarly, in addition to regulating the sensitivity to alcohol (Corl et al., 2009), EGFR activation contributes to the integrity of tight junctions between brain endothelial cells (Chen et al., 2011), and tight junctions are one of the most important structural elements of the BBB. Thus, substance use disorders may exacerbate the increased trafficking of peripheral monocytes to CNS, and in combination with compromised $\mathrm{BBB}$ function, may have significant consequences for individuals with co-morbid viral infection(s) (e.g., HCV and/or HIV).

As an initial step to identify mechanisms by which chronic viral infection and alcohol (ethanol; EtOH) induce abnormalities in $\mathrm{T}$ cell function, potentially facilitate neuroinvasion of LCMV, and contribute to CNS impairments, we exposed BALB/c mice

\section{REFERENCES}

Aharonovich, E., Nunes, E., and Hasin, D. (2003). Cognitive impairment, retention and abstinence among cocaine abusers in cognitive-behavioral treatment. Drug Alcohol Depend. 71, 207-211. doi: 10.1016/S0376-8716(03)00092-9

Bokemeyer, M., Ding, X. Q., Goldbecker, A., Raab, P., Heeren, M., Arvanitis, D., et al. (2011). Evidence for neuroinflammation and neuroprotection in HCV infection-associated encephalopathy. Gut 60, 370-377. doi: 10.1136/gut.2010.217976

Bolton, J. M., Robinson, J., and Sareen, J. (2009). Self-medication of mood disorders with alcohol and drugs in the national epidemiologic survey on alcohol and related conditions. J. Affect. Disord. 115, 367-375. doi: 10.1016/j.jad.2008.10.003

Brot, M. D., Rall, G. F., Oldstone, M. B., Koob, G. F., and Gold, L. H. (1997). Deficits in discriminated learning remain despite clearance of long-term persistent to $\mathrm{EtOH}$ and water (or water only) using a two-bottle choice paradigm, followed one week later by infection with either LCMV clone 13, LCMV Armstrong (causes acute infection), or vehicle. Mice were monitored for 60 days post-infection and continued to receive 24-h access to $\mathrm{EtOH}$ and water. Consumption of $\mathrm{EtOH}$ was associated with alterations in virus-specific CD8+ T cell expression and delayed viral clearance in mice with LCMV clone 13 infection (Loftis et al., 2015). Research to determine the effects of LCMV and alcohol exposure on CNS viral invasion and behavioral outcomes is in progress. Sriram et al. (2015) aptly note that; "LCMV has proven to be a great model to study chronic infections in mice as they induce a robust T cell response" (p. 8). Given that persistent CNS infection can lead to the generation of autoimmune responses and that the presence of viral proteins in the CNS can increase sensitivity to and susceptibility for substance abuse (Vigorito et al., 2015), more research is needed to provide a better understanding for the molecular basis of the neurotoxic combination of substance abuse and chronic viral infections, such as HCV and HIV. These investigative efforts will be instrumental in translating basic science and preclinical findings into clinical practice. For example, development of a database of infectious complications associated with substance use disorders could be established. Through the use of such a database (e.g., listing co-morbid HCV infection and opioid use disorder complicated by acute bacterial endocarditis, Wakeman et al., 2014), we may be better able to correlate key clinical observations with research findings, leading to more targeted (and potentially more aggressive) infection treatment strategies for patients with co-morbid substance use disorders.

\section{FUNDING}

This material is the result of work supported with resources and the use of facilities at the Veterans Affairs Portland Health Care System, Oregon Health \& Science University, and the Methamphetamine Abuse Research Center (NIDA P50DA018165), Portland, Oregon, USA. This work was supported by the U.S. Department of Veterans Affairs Biomedical Laboratory Research and Development Merit Review grant (\#I01 BX002061) to JL. The contents do not represent the views of the U.S. Department of Veterans Affairs or the United States Government.

viral infection in mice. J. Neurovirol. 3, 265-273. doi: 10.3109/135502897090 29467

Butt, A. A., Khan, U. A., McGinnis, K. A., Skanderson, M., and Kent Kwoh, C. (2007). Co-morbid medical and psychiatric illness and substance abuse in HCV-infected and uninfected veterans. J. Viral Hepat. 14, 890-896. doi: 10.1111/j.1365-2893.2007.00885.x

Callahan, M. K., Williams, K. A., Kivisäkk, P., Pearce, D., Stins, M. F., and Ransohoff, R. M. (2004). CXCR3 marks CD4+ memory T lymphocytes that are competent to migrate across a human brain microvascular endothelial cell layer. J. Neuroimmunol. 153, 150-157. doi: 10.1016/j.jneuroim.2004. 05.004

Carey, C. L., Woods, S. P., Rippeth, J. D., Gonzalez, R., Heaton, R. K., and Grant, I. (2006). Additive deleterious effects of methamphetamine dependence and immunosuppression on neuropsychological functioning in HIV infection. AIDS Behav. 10, 185-190. doi: 10.1007/s10461-005-9056-4 
Chen, F., Hori, T., Ohashi, N., Baine, A. M., Eckman, C. B., and Nguyen, J. H. (2011). Occludin is regulated by epidermal growth factor receptor activation in brain endothelial cells and brains of mice with acute liver failure. Hepatology 53, 1294-1305. doi: 10.1002/hep.24161

Christensen, J. E., de Lemos, C., Moos, T., Christensen, J. P., and Thomsen, A. R. (2006). CXCL10 is the key ligand for CXCR3 on CD8+ effector T cells involved in immune surveillance of the lymphocytic choriomeningitis virus-infected central nervous system. J. Immunol. 176, 4235-4243. doi: 10.4049/jimmunol.176.7.4235

Coley, J. S., Calderon, T. M., Gaskill, P. J., Eugenin, E. A., and Berman, J. W. (2015). Dopamine increases CD14+CD16+ monocyte migration and adhesion in the context of substance abuse and HIV neuropathogenesis. PLOS ONE 10:e0117450. doi: 10.1371/journal.pone.0117450

Corl, A. B., Berger, K. H., Ophir-Shohat, G., Gesch, J., Simms, J. A., Bartlett, S. E., et al. (2009). Happyhour, a Ste20 family kinase, implicates EGFR signaling in ethanol-induced behaviors. Cell 137, 949-960. doi: 10.1016/j.cell.2009. 03.020

Crum, R. M., Mojtabai, R., Lazareck, S., Bolton, J. M., Robinson, J., Sareen, J., et al. (2013). A prospective assessment of reports of drinking to selfmedicate mood symptoms with the incidence and persistence of alcohol dependence. JAMA Psychiatry 70, 718-726. doi: 10.1001/jamapsychiatry. 2013.1098

Fals-Stewart, W. (1993). Neurocognitive defects and their impact on substance abuse treatment. J. Addict. Off. Couns. 13, 46-57. doi: 10.1002/j.21611874.1993.tb00083.x

Fuller, B. E., Loftis, J. M., Rodriguez, V. L., McQuesten, M. J., and Hauser, P. (2009). Psychiatric and substance use disorders comorbidities in veterans with hepatitis C virus and HIV coinfection. Curr. Opin. Psychiatry 22, 401-408. doi: 10.1097/YCO.0b013e32832cadb9

Gaskill, P. J., Calderon, T. M., Coley, J. S., and Berman, J. W. (2013). Drug induced increases in CNS dopamine alter monocyte, macrophage and $\mathrm{T}$ cell functions: implications for HAND. J Neuroimmune Pharmacol. 8, 621-642. doi: 10.1007/s11481-013-9443-y

Gavrilin, M. A., Mathes, L. E., and Podell, M. (2002). Methamphetamine enhances cell-associated feline immunodeficiency virus replication in astrocytes. J. Neurovirol. 8, 240-249. doi: 10.1080/13550280290049660

Haorah, J., Schall, K., Ramirez, S. H., and Persidsky, Y. (2008). Activation of protein tyrosine kinases and matrix metalloproteinases causes blood-brain barrier injury: novel mechanism for neurodegeneration associated with alcohol abuse. Glia 56, 78-88. doi: 10.1002/glia.20596

Kousik, S. M., Napier, T. C., and Carvey, P. M. (2012). The effects of psychostimulant drugs on blood brain barrier function and neuroinflammation. Front. Pharmacol. 3:121. doi: 10.3389/fphar.2012.00121
Loftis, J. M., Matthews, A. M., and Hauser, P. (2006). Psychiatric and substance use disorders in individuals with hepatitis C: epidemiology and management. Drugs 66, 155-174. doi: 10.2165/00003495-200666020-00003

Loftis, J. M., Taylor, J., Raué, H. P., Fuller, B., Hauser, P., and Slifka, M. (2015). An animal model that investigates the mechanisms of combined CNS injury and possible therapeutic strategies for co-morbid alcohol dependence and chronic viral infection. Brain Behav. Immun. 49(Suppl.), e32-e33. doi: 10.1016/j.bbi.2015.06.128

Martínez-Raga, J., Marshall, E. J., Keaney, F., Best, D., Ball, D., and Strang, J. (2001). Hepatitis B and C in alcohol-dependent patients admitted to a UK alcohol inpatient treatment unit. Addict. Biol. 6, 363-372. doi: $10.1080 / 13556210020077082$

Northrop, N. A., and Yamamoto, B. K. (2012). Persistent neuroinflammatory effects of serial exposure to stress and methamphetamine on the blood-brain barrier. J. Neuroimmune Pharmacol. 7, 951-968. doi: 10.1007/s11481-0129391-y

Potula, R., Haorah, J., Knipe, B., Leibhart, J., Chrastil, J., Heilman, D., et al. (2006). Alcohol abuse enhances neuroinflammation and impairs immune responses in an animal model of human immunodeficiency virus1 encephalitis. Am. J. Pathol. 168, 1335-1344. doi: 10.2353/ajpath.2006. 051181

Sriram, U., Haldar, B., Cenna, J. M., Gofman, L., and Potula, R. (2015). Methamphetamine mediates immune dysregulation in a murine model of chronic viral infection. Front. Microbiol. 6:793. doi: 10.3389/fmicb.2015.00793

Vigorito, M., Connaghan, K. P., and Chang, S. L. (2015). The HIV-1 transgenic rat model of neuroHIV. Brain Behav. Immun. 48, 336-349. doi: 10.1016/j.bbi.2015.02.020

Wakeman, S. E., Ghoshhajra, B. B., Dudzinski, D. M., Wilens, T., and Slavin, P. L. (2014). Case records of the Massachusetts General Hospital. Case 352014: a 31-year-old woman with fevers, chest pain, and a history of HCV infection and substance-use disorder. N. Engl. J. Med. 371, 1918-1926. doi: 10.1056/NEJMcpc1407131

Conflict of Interest Statement: The author declares that the research was conducted in the absence of any commercial or financial relationships that could be construed as a potential conflict of interest.

Copyright $(2015$ Loftis. This is an open-access article distributed under the terms of the Creative Commons Attribution License (CC BY). The use, distribution or reproduction in other forums is permitted, provided the original author(s) or licensor are credited and that the original publication in this journal is cited, in accordance with accepted academic practice. No use, distribution or reproduction is permitted which does not comply with these terms. 